\title{
Bioedusiana
}

Blology

http://jurnal.unsil.ac.id/index.php/bioed

Education

Department

Universitas Siliwang

DOI: https://doi.org/10.37058/bioed.v5i2.2216

\section{Pengembangan Mobile Virtual Laboratorium pada Pembelajaran Praktikum Materi Pencemaran Air}

\section{Development of Mobile Virtual Laboratory on Water Pollution Material Practicum Learning}

\author{
Zainal Arifin ${ }^{1 *}$, Elvira Destiansari ${ }^{2}$, Susy Amizera ${ }^{3}$ \\ 1,2,3 Program Studi Pendidikan Biologi FKIP Universitas Sriwijaya, Jalan Raya Palembang-Prabumulih \\ Km. 32, Indralaya, Sumatera Selatan 30662
}

\begin{abstract}
Abstrak
Pembelajaran yang memerlukan laboratorium dengan alat dan bahan yang memenuhi standar sudah seharusnya dapat dilaksanakan dengan baik terutama pada materi yang berkaitan dengan prinsip ekologi seperti materi pencemaran air. Namun keterbatasan akan hal tersebut menjadikan pemilihan kegiatan praktikum dengan menggunakan virtual lab menjadi salah satu alternatif dalam membantu kegiatan belajar. Penelitian ini dilaksanakan dengan tujuan untuk mengembangkan mobile virtual lab pada materi pencemaran air, melakukan validasi baik materi, tampilan dan bahasa serta mengetahui respon mahasiswa terhadap penggunaannya. Metode yang digunakan dalam penelitian ini adalah metode penelitian pengembangan yang terdiri dari tahap studi pendahuluan, tahap perencanaan penelitian, dan tahap pengembangan produk (desain, produksi, dan validasi produk). Hasil penelitian ini menunjukkan bahwa diperoleh produk mobile virtual lab berdasarkan beberapa pertimbangan antara lain berdasarkan hasil analisis kebutuhan serta hasil masukan dari ahli materi, bahasa, dan tampilan. Uji coba yang dilakukan sampai ke tahap skala kecil memperoleh hasil bahwa pada aspek materi dengan indeks rata-rata $88 \%$ terkategori sangat baik, aspek bahasa dengan indeks rata-rata 91,11\% terkategori sangat baik, dan aspek tampilan dengan indeks rata-rata 94,07\% juga terkategori sangat baik. Ini menujukkan bahwa mobile virtual lab yang dikembangkan sudah sangat baik dalam hal materi, bahasa, dan tampilan. Perbaikan dan saran yang diberikan cukup mendukung untuk melanjutkan ke tahap pengujian skala besar yang pada akhirnya diharapkan dapat diaplikasikan lebih luas dan bermanfaat untuk proses pembelajaran.
\end{abstract}

Kata kunci: Pengembangan; Mobile virtual laboratorium; Pencemaran Air

\section{Abstract}

Learning that requires a laboratory with tools and materials that meet the standards should be carried out properly, especially on materials related to ecological principles such as water pollution material. However, these limitations make the selection of practicum activities using virtual labs an alternative in helping learning activities. This research was carried out with the aim of developing a mobile virtual lab on water pollution material, validating both the material, appearance and language as well as knowing student responses to its use. The method used in this research is a development research method such as the preliminary study stage, the research planning stage, and the product development stage (design, production, and product validation. The results of this study indicate that a mobile virtual lab product is obtained based on Several considerations, among others, are based on the results of the analysis of needs and the results of input from material, language, and display experts. Tests carried out to the small scale stage showed that the material aspect with an average index of $88 \%$ was very good, the language aspect was an average of $91.11 \%$ is categorized as very good, and the display aspect with an average index of $94.07 \%$ is also in very good category. This shows that the mobile virtual lab developed is very good in terms of material, language, and appearance. the suggestions given are sufficiently supportive to proceed to the large-scale testing phase $y$ which in the end is expected to be applied more widely and be useful for the learning process.

Keywords: Development; Mobile virtual laboratory; Water pollution

\section{Article History}

Received: October, 30 2020; Accepted: December, 24 ${ }^{\text {th }} 2020$; Published: December, $31^{\text {st }} 2020$

Corresponding Author*

Zainal Arifin, Program Studi Pendidikan Biologi FKIP Universitas Sriwijaya, Email: zainal arifin@fkip.unsir.ac.id 


\section{PENDAHULUAN}

Salah satu sarana pendukung yang dapat menunjang keterampilan mahasiswa khususnya dalam kegiatan investigasi dan eksperimen pada suatu produk adalah laboratorium. Namun beberapa materi pembelajaran yang memerlukan laboratorium dengan alat dan bahan yang harus memenuhi standar yang telah ditetapkan sehingga tidak dimungkinkan untuk dilakukan kegiatan praktikum pada materi tersebut. Salah satu materi pembelajaran yang memerlukan laboratorium dengan biaya, peralatan, bahan dan antisipasi resiko kerja yang harus memenuhi standar yaitu materi yang berkaitan dengan prinsip ekologi. Mata kuliah yang berhubungan dengan prinsip ekologi yaitu mata kuliah ekologi hewan. Salah satu capaian yang harus dicapai mahasiswa yaitu memahami konsep hewan dan lingkungannya yang terdiri dari faktor- faktor lingkungan hewan, respon dasar hewan terhadap berbagai perubahan kondisi dan sumber daya, kisaran toleransi hewan terhadap perubahan lingkungan serta respon dan mekanisme adaptasi hewan. Pada materi ini, kegiatan praktikumnya sebatas pada dampak pencemaran dibandingkan penyebab dan kualitas lingkungan yang diukur. Mahasiswa menjadi kurang mampu untuk merumuskan gagasan pemecahan masalah dikarenakan kurangnya pengetahuan dalam menganalisis perubahan data yang berkaitan dengan masalah pencemaran lingkungan

Keterbatasan fasilitas laboratorium dapat diatasi dengan menggunakan virtual lab sebagai alternatif lingkungan belajar yang dapat membantu dalam kegiatan praktikum (Tatli \& Ayas, 2013). Hasil penelitian (Suryanti et al., 2019) menunjukkan bahwa berdasarkan persepsi Mahasiswa bahwa sebagian besar mahasiswa menunjukkan persepsi positif terhadap penggunaan Virtual Laboratory. Virtual lab bermanfaat juga dalam memberikan kesempatan kepada mahasiswa untuk meningkatkan kepercayaan diri dan pengetahuannya (Coleman \& Smith, 2019). Selain itu, Peserta didik dapat mempraktikkan pengetahuan yang diperoleh secara teoritis dengan menggunakan Virtual Lab tanpa khawatir kendala ruang dan waktu (Guzmán et al., 2005). Ini merupakan dasar untuk lebih mengembangkan aplikasi virtual laboratory sebagai salah satu alternatif untuk menciptakan pembelajaran yang menarik, membantu meningkatkan penguasaan konsep dan mengatasi keterbatasan fasilitas laboratorium

Penggunaan virtual lab dalam proses pembelajaran dapat membantu mahasiswa dalam hal proses investigasi dan eksperimen tanpa memikirkan keterbatasan waktu, alat dan bahan yang selama ini mejadi kendala pada kegiatan praktikum. Hal ini sejalan dengan hasil studi Babateen bahwa penggunaan virtual Laboratorium memiliki pengaruh positif dalam menyediakan pengalaman untuk memperoleh keterampilan dalam pembelajaran Biologi (Babateen, 2011). Berkaitan dengan hal tesrsebut, penggunaan Laboratorium Virtual berbasis Discover Learning pada materi Biologi mempermudah pemahaman materi siswa terutama yang bersifat abstrak dan media laboratorium virtual layak digunakan dalam pembelajaran (Nisa \& Rinanto, 2019). Menurut Swan dan Angela, mahasiswa memiliki respon yang positif terhadap 
Virtual Lab biologi. Mahasiswa biologi yang melaksanakan ujian praktik merasa lebih berhasil dan efektif menggunakan virtual lab. Berkaitan dengan hal tersebut, peserta didik dapat memperoleh informasi salah satunya melalui Virtual lab. Penerapan virtual lab dalam bentuk game memiliki potensi besar dalam mendukung proses belajar mengajar di bidang sains ((Liu et al., 2015). Berdasarkan penelitian mengenai penggunaan laboratorium virtual pada pembelajaran pratikum tersebut dapat terlihat bahwa penggunaan laboratorium virtual dapat meningkatkan sikap ilmiah serta mampu menjadi solusi keterbatasan peralatan dan bahan pada kegiatan praktikum sehingga pada pembuatan laboratorium virtual menggunakan teknologi ini difokuskan pada materi yang berkaitan dengan perubahan lingkungan khususunya pada konsep pencemaran air. Adapun tujuan dari penelitian ini, yaitu untuk mengembangkan mobile virtual lab pada materi pencemaran air

\section{METODE}

Penelitian yang akan dilaksanakan adalah penelitian dan pengembangan (Research and Development) menurut Borg \& Gall (1989) dan tahapan yang telah dilaksanakan yaitu sampai dengan tahap uji coba skala kecil. Aplikasi yang dikembangkan menggunakan Corel Draw X6 dan flow.io. Penelitian ini dilaksanakan pada bulan Agustus s.d. September 2020. Populasi dan sampel penelitian ini adalah Mahasiswa semester V pada Program Studi Pendidikan Biologi Fakultas Keguruan dan Ilmu Pendidikan Universitas Sriwijaya. Hal ini dikarenakan mahasiswa pada semester ini mulai dituntut untuk memiliki keterampilan berfikir kritis dan sikap ilmiah dalam merespon kejadian yang terjadi di lingkungan sekitar dan mahasiswa tersebut sedang mengambil mata kuliah yang berkaitan dengan materi yang dikaji. Teknik pengambilan data pada penelitian ini dengan cara melakukan analisis kebutuhan mahasiswa, melakukan validasi aspek materi, tampilan, dan bahasa pada produk; dan penggunaan angket hasil uji coba produk. Tekhnik analisis data yaitu dengan menggunakan kriteria penilaian data persentase untuk hasil validasi produk, sedangkan untuk angket hasil uji coba produk menggunakan kategorisasi indeks rata-rata pada setiap aspek penilaian. Instrumen penelitian yang digunakan antara lain lembar validasi produk dan lembar angket. Indikator penilaian pada uji coba produk antara lain pada aspek materi (kesesuaian dengan capaian pembelajaran dan sistematis), pada aspek bahasa (kesesuaian dengan tata bahasa), dan pada aspek tampilan (desain dan tampilan fisik virtual lab).

Prosedur penelitian ini antara lain :

1. Tahap studi pendahluan (studi pustaka dan analisis kebutuhan)

2. Tahap pengembangan produk seperti desain, produksi dan validasi.

3. Tahap uji coba produk ke mahasiswa dan revisi 


\section{HASIL DAN PEMBAHASAN}

Hasil penelitian ini adalah produk laboratorium virtual yang dihasilkan pada tahap awal masih bersifat prototype. Produk mobile virtual laboratory disajikan pada Tabel 1 berikut.

Tabel 1. Tampilan Prototype Mobile Virtual Laboratorium

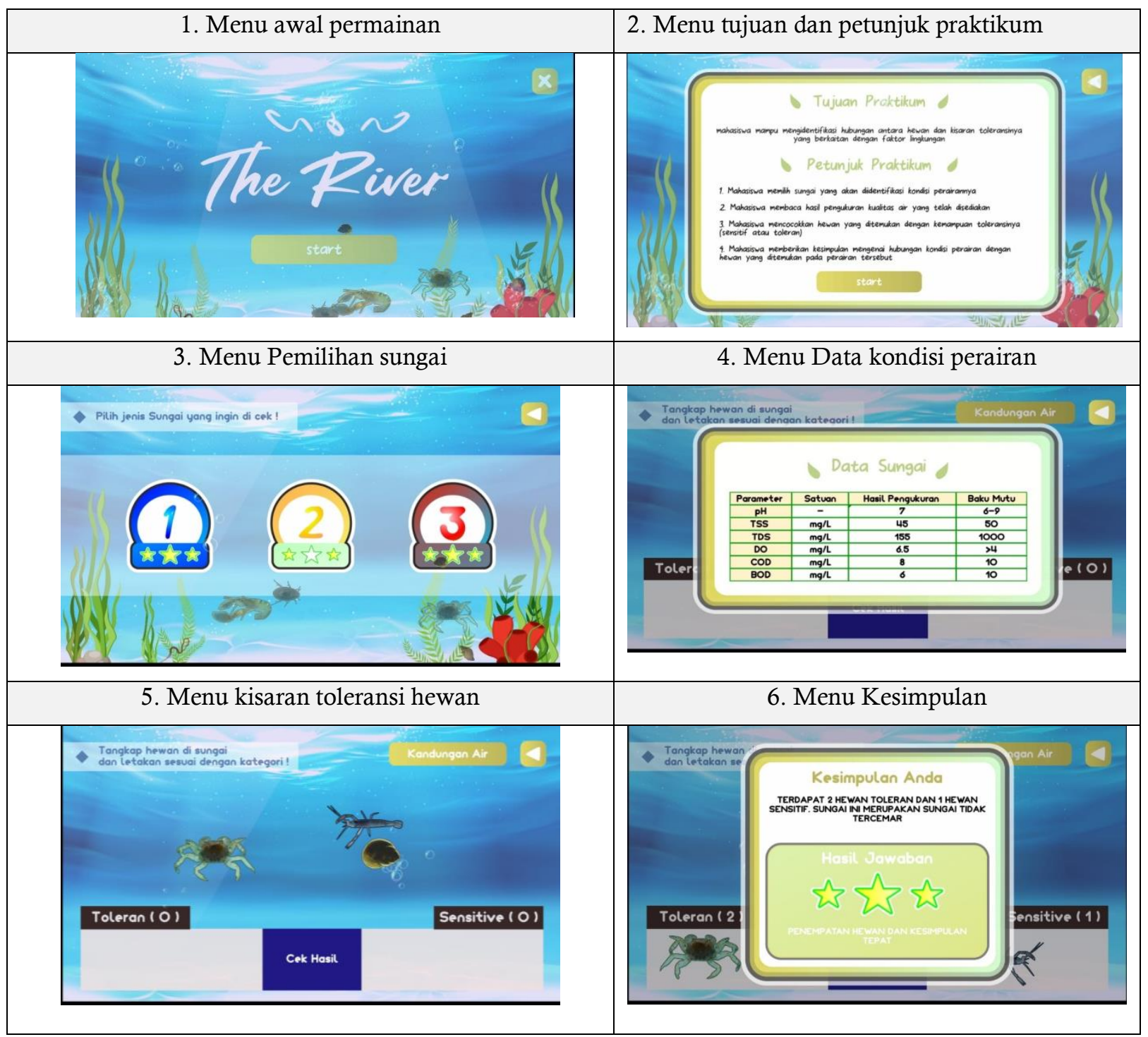

Pada tahap ujicoba one to one dilakukan terhadap tiga orang mahasiswa berdasarkan hasil tes awal (pre-test). Berdasarkan hasil ujicoba tersebut diperoleh kesimpulan bahwa menurut mahasiswa terdapat bagian yang perlu ditambahkan. Bagian yang perlu ditambahkan tersebut adalah pengenalan karakter, gambar, nama dan sifat hewan. Selain itu, sebaiknya ditambahkan sedikit materi pada praktikum virtual tersebut. Setelah tahapan one to one dilanjutkan dengan tahapan revisi. Hasil revisi ini disebut dengan mobile virtual lab Prototype ke 2. Kemudian Prototype 2 dilakukan ujicoba kembali ke dalam skala kecil. 
Kategori pada setiap aspek penilaian didasarkan pada hasil persentase indeks rata-rata. Hasil uji coba skala kecil dan kategori dari setiap aspek penilaian disajikan pada Tabel 2 berikut.

Tabel 2. Hasil Uji Coba Skala Kecil Mobile virtual lab

\begin{tabular}{|c|c|c|c|c|c|}
\hline No & $\begin{array}{c}\text { Aspek } \\
\text { Penilaian }\end{array}$ & Indikator penilaian & $\begin{array}{c}\text { Pernyataan } \\
\text { Nomor }\end{array}$ & $\begin{array}{c}\text { Indeks } \\
\text { Rata-rata } \\
(\%)\end{array}$ & Kategori \\
\hline 1 & Materi & $\begin{array}{l}\text { Kegiatan yang disajikan pada } \\
\text { Mobile virtual lab sesuai dengan } \\
\text { capaian pembelajaran, sistematis, } \\
\text { merangsang rasa ingin tahu dan } \\
\text { mendukung proses belajar }\end{array}$ & $1-5$ & 88 & SB \\
\hline 2 & Bahasa & $\begin{array}{l}\text { Bahasa yang digunakan pada } \\
\text { Mobile virtual lab sesuai dengan } \\
\text { EYD, mudah dipahami, dan } \\
\text { komunikatif }\end{array}$ & $6-9$ & 91,11 & SB \\
\hline 3 & Tampilan & $\begin{array}{l}\text { Jenis dan ukuran huruf, lay out, } \\
\text { dan desain pada Kegiatan } \\
\text { praktikum Mobile virtual lab yang } \\
\text { disajikan sesuai serta memuat } \\
\text { petunjuk belajar }\end{array}$ & $10-15$ & 94,07 & SB \\
\hline
\end{tabular}

Keterangan :

$\mathrm{SB}=$ Sangat Baik; $\mathrm{B}=$ Baik; $\mathrm{C}=$ Cukup; $\mathrm{KB}=$ Kurang Baik; $\mathrm{TB}=$ Tidak Baik.

\section{Pembahasan}

Berdasarkan hasil yang diperoleh bahwa pengembangan desain mobile virtual lab ini dilakukan dengan beberapa tahapan. Sebelum mendesain produk. Peneliti melakukan analisis kebutuhan dan pretest. Analisis kebutuhan dilakukan untuk mengetahui dan menjaring data tentang kebutuhan mahasiswa terhadap virtual lab pada materi yang telah dipilih. Selain itu juga untuk mengetahui bentuk virtual lab yang seperti apa yang dibutuhkan oleh mahasiswa yaitu apakah virtual lab berbasis android atau PC kemudian apakah virtual lab yang dikembangkan ke dalam bentuk permainan atau game. Berdasarkan hasil analisis kebutuhan, 90,78\% mahasiswa setuju untuk merancang virtual lab dalam bentuk game. Hal ini betujuan agar proses pembelajaran lebih kreatif dan inovatif sehingga mahasiswa lebih tertarik untuk mempelajari materi ini. Game merupakan salah satu fitur yang banyak diminati baik anak - anak maupun dewasa sehingga pengembangan game berbasis edukasi dapat menjadi suatu alternatif dalam inovasi suatu pembelajaran agar dapat menarik minta mahasiswa dalam proses belajar (Rosita dewi, 2017). Penerapan virtual lab dalam bentuk game memiliki potensi besar dalam mendukung proses belajar mengajar di bidang sains (Liu et al., 2015). Dengan demikian pengembangan virtual lab dalam bentuk game diharapkan dapat meningkatkan hasil belajar mahasiswa khususnya pada materi pencemaran.

Berdasarkan pertimbangan tersebut, maka dibuatlah story board. Selain itu juga dilakukan validasi oleh ahli materi, ahli bahasa dan tampilan yang pada akhirnya diperoleh desain seperti yang disajikan pada Tabel 1. Di dalam mobile virtual lab tersebut terdapat beberapa menu seperti 
menu awal permainan, menu tujuan dan petunjuk praktikum, menu pemilihan sungai, menu data kondisi perairan, menu kisaran toleransi hewan dan menu kesimpulan. Kemudian tahapan selajutnya dilakukan uji coba one to one, kemudian direvisi dan dilanjutkan uji coba ke skala kecil. Hasil ujicoba yang diperoleh sampai pada tahap skala kecil disajikan pada Tabel 2. Hasil uji coba tersebut diperoleh dengan merujuk pada aspek penilaian dan indikator penilaian yang terbagi ke dalam hal terkait materi, bahasa, dan tampilan.

Hasil uji coba tahap skala kecil menunjukkan indeks rata-rata yang dikategorikan ke dalam kategori sangat baik. Pada aspek materi dengan indeks rata-rata $88 \%$ terkategori sangat baik, pada aspek bahasa dengan indeks rata-rata 91,11\% terkategori sangat baik, dan pada aspek tampilan dengan indeks rata-rata 94,07\% juga terkategori sangat baik. Ini menujukkan bahwa mobile virtual lab yang dikembangkan sudah sangat baik dalam hal materi, bahasa, dan tampilan. Berkaitan dengan hal tersebut, hasil penelitian (Swan \& O’Donnell, 2009) menunjukkan bahwa mahasiswa memiliki respon yang positif terhadap virtual lab biologi. Mahasiswa biologi yang melaksanakan ujian praktik merasa lebih berhasil dan efektif menggunakan virtual lab.

Pengembangan mobile virtual lab merupakan konversi bentuk pembelajaran ke dalam bentuk penggunaan teknologi digital oleh guru. Guru sains dapat menggunakan teknologi digital sebagai salah satu prospek pembaharuan dalam kurikulum. Hal ini selain dapat mengembangkan kemampuannya dalam penguasaan teknologi, tetapi juga dapat mengembangkan profesionalitasnya sebagai pengajar (Fernandes et al., 2020). Sehubungan dengan hal tersebut Virtual lab bermanfaat dalam memberikan kesempatan kepada mahasiswa untuk meningkatkan kepercayaan diri dan pengetahuannya tanpa khawatir kendala ruang dan waktu (Coleman \& Smith, 2019). Selain itu, Pembelajaran secara online menjadi salah satu bentuk kegiatan yang dilaksanakan oleh pendidik pada Masa Pandemi Covid-19. Penggunaan eksperimen dan laboratorium virtual menjadi kegiatan yang memungkinkan untuk dilaksanakan dalam rangka membantu peserta mengembangkan keterampilan praktikum walaupun pada kenyataannya tidak dapat secara utuk menggantikan interaksi fisik peserta didik dengan peralatan praktikum (Glassey \& Magalhães, 2020).

\section{SIMPULAN}

Pengembangan mobile virtual lab yang dilakukan dilakukan dengan beberapa tahapan seperti tahap studi pendahluan, pengembangan produk seperti desain, produksi dan validasi. Selanjutnya tahap uji coba produk ke mahasiswa dan dilakukan revisi. Produk yang dikembangkan berdasarkan hasil studi pendahuluan dan validasi dari ahli materi, bahasa dan tampilan. Penulis pada artikel ini menguraikan hasil ujicoba produk sampai ke tahap skala kecil. Hasil yang diperoleh bahwa produk yang dikembangkan sudah terkategori sangat baik dari sisi materi, bahasa dan tampilan. Walaupun demikian, uji coba skala besar tetap dilakukan sehingga 
diharapkan pada akhirnya diperoleh produk yang dapat dimanfaatkan secara luas oleh mahasiswa dan dosen di dalam proses belajar dan mengajar terutama di dalam pembelajaran online pada saat ini.

\section{UCAPAN TERIMA KASIH}

Penulis mengucapkan terima kasih kepada berbagai pihak yang telah membantu dalam penulisan artikel ini. Ucapan terima kasih disampaikan kepada Rektor dan Ketua Lembaga Penelitian Universitas Sriwijaya, yang telah memberikan bantuan dana DIPA BLU Unsri untuk penelitian pada skema Sateks sehingga penelitian ini dapat dilaksanakan. Penulis juga mengucapkan terima kasih atas dukungan, saran serta kritik yang telah diberikan baik oleh mahasiswa dan dosen FKIP Pendidikan Biologi Universitas Sriwijaya.

\section{REFERENSI}

Babateen, H. (2011). The role of Virtual Laboratories in Science Education. 5th International Conference on Distance Learning and Education, 12, 100-104. https://pdfs.semanticscholar.org/a98d/73d731659b5e9053f10b3213daeb85f630eb.pdf

Coleman, S. K., \& Smith, C. L. (2019). Evaluating the benefits of virtual training for bioscience students. Higher Education Pedagogies, 4(1), 287-299. https://doi.org/10.1080/23752696.2019.1599689

Fernandes, G. W. R., Rodrigues, A. M., \& Ferreira, C. A. (2020). Professional Development and Use of Digital Technologies by Science Teachers: a Review of Theoretical Frameworks. Research in Science Education, 50(2), 673-708. https://doi.org/10.1007/s11165018-9707-x

Glassey, J., \& Magalhães, F. D. (2020). Virtual labs - love them or hate them, they are likely to be used more in the future. Education for Chemical Engineers, 33, 76-77. https://doi.org/10.1016/j.ece.2020.07.005

Guzmán, J. L., Rodríguez, F., Berenguel, M., \& Dormido, S. (2005). Virtual lab for teaching greenhouse climatic control. In IFAC Proceedings Volumes (IFAC-PapersOnline) (Vol. 38, Issue 1). IFAC. https://doi.org/10.3182/20050703-6-cz-1902.02286

Liu, D., Valdiviezo-Díaz, P., Riofrio, G., Sun, Y. M., \& Barba, R. (2015). Integration of Virtual Labs into Science E-learning. Procedia Computer Science, 75(Vare), 95-102. https://doi.org/10.1016/j.procs.2015.12.224

Nisa, S. K., \& Rinanto, Y. (2019). Pengembangan Media Pembelajaran Laboratorium Virtual Berbasis Discovery Learning pada Materi Sistem Ekskresi untuk Kelas XI MIPA Development of Virtual Laboratory Learning Media Based on Discovery Learning on Excression System Materials for Class XI MIPA. 8. Bio-Pedagogi : Jurnal Pembelajaran Biologi. 8(2), $120-126$.

Rosita dewi, F. (2017). Pengembangan Media Pembelajaran Berbasis Game Edukasi Bergenre Side-Scroliing Platformer. It-Edu, 2(01), 92-96.

Suryanti, E., Fitriani, A., Redjeki, S., \& Riandi, R. (2019). Persepsi Mahasiswa terhadap Penggunaan Virtual Laboratory dalam Pembelajaran Biologi Molekuler. Journal of Natural Science and Integration, 2(2), 32. https://doi.org/10.24014/jnsi.v2i2.7884

Swan, A. E., \& O'Donnell, A. M. (2009). The contribution of a virtual biology laboratory to college students' learning. Innovations in Education and Teaching International, 46(4), 405-419. https://doi.org/10.1080/14703290903301735 
Tatli, Z., \& Ayas, A. (2013). Effect of a Virtual Chemistry Laboratory on Students ' Achievement Technologies for the Seamless Integration of Formal and Informal Learning. Journal of Educational Technology \& Society, 16(1), 159-170. https://www.jstor.org/stable/jeductechsoci.16.1.159 